\title{
Las poderosas: rompiendo el silencio
}

\section{María R. Matz}

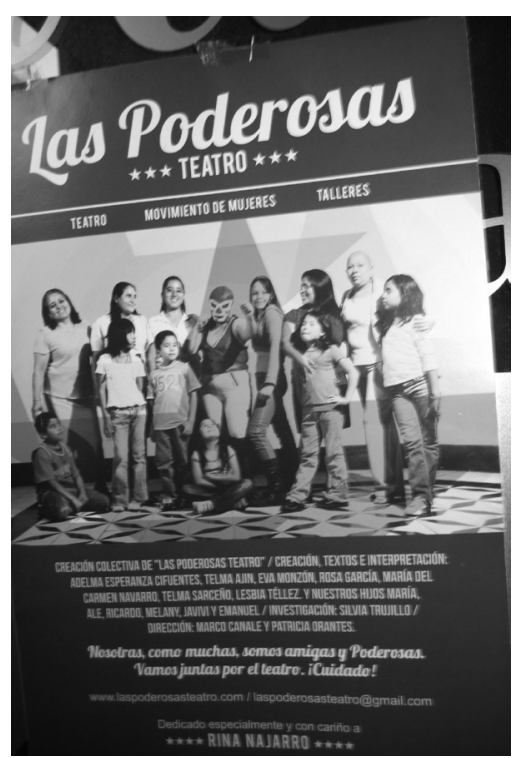

Cartel de la obra Las Poderosas, presentada el 21 de octubre del 2011 dentro del XXVI Festival de Teatro Iberoamericano de Cádiz, con Lesbia Téllez en el centro vestida de luchadora. Foto: María R. Matz.

En Cádiz, durante el XV Encuentro de mujeres de Iberoamérica en las artes escénicas, participaron Las Poderosas, colectivo teatral de mujeres guatemaltecas, quienes mediante la utilización del biodrama o teatro documental han roto el silencio de la violencia ejercida contra ellas. En la obra Las poderosas, presentada el 21 de octubre del 2011 dentro del XXVI Festival de Teatro Iberoamericano de Cádiz, nos encontramos no sólo con la plasmación del abuso físico sino también síquico, mostrándose la importancia que posee la educación en el traspaso de los valores patriarcales.

La obra se desarrolla en un espacio escénico prácticamente vacío; en el lado izquierdo, se observa una mesa rectangular con una lamparita encendida la cual sirve como espacio de ensayo, de creación, desde donde las componentes del colectivo apoyan a la compañera en escena mientras ésta narra su historia al público. La obra se compone de quince viñetas de las cuales sólo una sigue el modelo aristotélico. En ella, el personaje representado por la actriz Lesbia Téllez crece, consigue sus sueños y finalmente se transforma en una luchadora de lucha libre que vence a sus miedos y fantasmas para de esta manera pasar a convertirse en la poderosa Lesbia Téllez. Las diferentes escenas trasmiten 
el poder de la propia mujer a la hora de cambiar su situación; no siendo esta obra un mensaje publicitario contra la violencia de género, sino que mediante las historias de las propias actrices, la audiencia, catárticamente, se identifica con las situaciones que presencia despertándose su conciencia social. Cada una de Las Poderosas eligió presentar una historia propia que fue recreada por las mismas actrices a través de un largo proceso de investigación y creación donde entre otros elementos se incluyeron entrevistas que ellas mismas se realizaban.

El proceso teatral se ha mezclado con la vida de estas mujeres; la obra no es estática sino que se encuentra en perenne evolución al adaptarse a las vivencias de sus protagonistas. Un ejemplo lo tenemos en la representación del pasado octubre en Cádiz donde David, el hijo de Telma acababa de ser puesto en libertad y esta parte de la obra ya no podía ser la misma o en la inclusión de una escena donde se lee la carta escrita por Marco Canale, director del colectivo, al morir Rina Najarro, una de las componentes del grupo. Igualmente, una de las características de este colectivo es, ya desde sus primeros ensayos, la participación de sus hijos en el proceso teatral. La presencia de estas voces infantiles tiene un mensaje claro que dar, puesto que partiendo desde sus vivencias es como la sociedad del futuro podrá cambiar.

Mediante su fuerza y su deseo de luchar, hacen que sus palabras se conviertan en un instrumento de sanación, pues como ellas mismas afirman, "motivamos a aquellas que estén sufriendo la violencia a que denuncien la situación de abuso". Su valor radica no sólo en el elemento autobiográfico de la obra sino en la valentía de este colectivo que presenta sus historias ante el silencio de una sociedad incapaz de hacer frente a la violencia de género.

\section{University of Massachusetts Lowell}

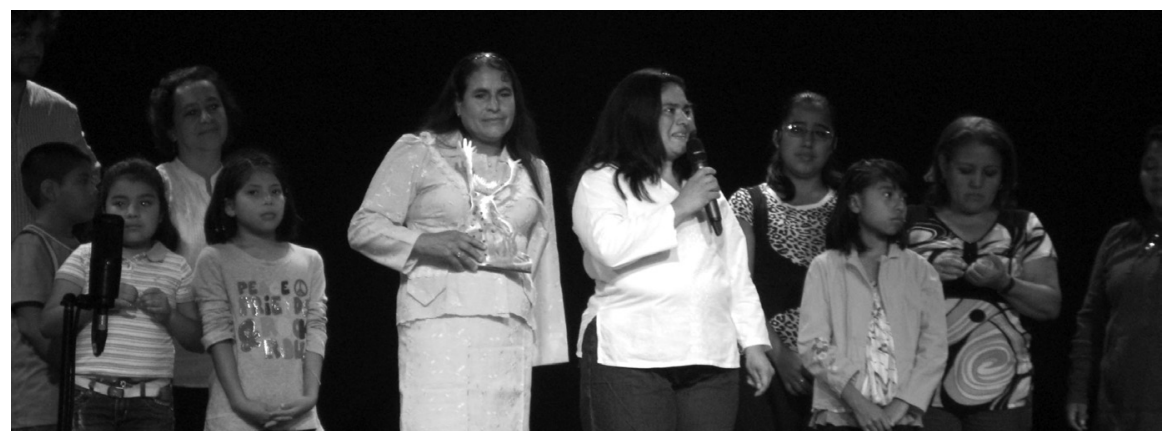

Las Poderosas recibieron el premio "La Glo" en el XV Encuentro de mujeres de Iberoamérica en las artes escénicas. Foto: María R. Matz. 